\title{
Benthic assemblages of rock pools in northern Portugal: seasonal and between-pool variability
}

\author{
IACOPO BERTOCCI ${ }^{1}$, RITA ARAÚJO ${ }^{1}$, MÓNICA INCERA ${ }^{2}$, FRANCISCO ARENAS ${ }^{1}$, \\ RUI PEREIRA ${ }^{1}$, HELENA ABREU ${ }^{1,3}$, KIM LARSEN $^{1}$ and ISABEL SOUSA-PINTO ${ }^{1,4}$ \\ ${ }^{1}$ CIIMAR/CIMAR, Centro Interdisciplinar de Investigação Marinha e Ambiental, Rua dos Bragas, 289, 4050-123, Porto, \\ Portugal. E-mail: ibertocci@ ciimar.up.pt \\ ${ }^{2}$ Centro Tecnológico del Mar - Fundación CETMAR, C/Eduardo Cabello, s/n E-36208, Bouzas, Vigo, Spain. \\ ${ }^{3}$ Daithi O'Murchu Marine Research Station, Gearhies-Bantry, Ireland. \\ ${ }^{4}$ Department of Biology, Faculty of Sciences, University of Porto, Rua do Campo Alegre s/n, 4169-007, Porto, Portugal.
}

SUMMARY: We investigated the seasonal (winter vs summer and within season) and spatial (between-pool) variability of benthic assemblages of rock pools at mid-intertidal level along the shore of Viana do Castelo (North Portugal). Physical traits of rock pools, including size, depth and position along the shore, were also compared between pools. While pools did not differ for any of the examined physical traits, results indicated a clear seasonal difference in the structure of assemblages, including a total of 49 macroalgal and 13 animal taxa. This finding was driven by six taxa that are more abundant in winter (the reefforming polychaete Sabellaria alveolata, the articulated coralline algae Corallina spp., the brown alga Bifurcaria bifurcata, the encrusting coralline alga Lithophyllum incrustans, the red alga Chondracanthus acicularis and the grazing snails Gibbula spp.) and four algal taxa that are more abundant in summer (the invasive brown Sargassum muticum, the green Ulva spp., the kelp Laminaria ochroleuca and the filamentous red Ceramium spp.). These data provide a new contribution to the knowledge of rock pool systems and have potential implications for monitoring programmes aimed at assessing ecological modifications related to natural and anthropogenic disturbances and for identifying processes responsible for the variability of rock pool assemblages.

Keywords: rock pools, rocky intertidal, seasonal variability, benthos, Sabellaria alveolata, Portugal.

RESUMEN: COMUNIDADES BENTÓNICAS DE CHARCAS ROCOSAS DEL NORTE DE PORTUGAL: VARIABILIDAD ESTACIONAL Y ENTRE CHARCAS. - Investigamos la variabilidad estacional (invierno vs verano y entre estaciones) y espacial (entre charcas) de las comunidades bentónicas en charcas rocosas del nivel intermareal medio a lo largo de la costa de Viana do Castelo (Norte de Portugal). Además comparamos los parámetros físicos entre las charcas, incluyendo el tamaño, temperatura y posición a lo largo de la costa. Mientras que las charcas no difieren para ninguno de los parámetros físicos examinados, los resultados indican una clara diferencia estacional en la estructura de las comunidades, las cuales incluyen un total de 49 taxones de algas y 13 de animales. Estos resultados fueron inducidos por seis taxones más abundantes en invierno (el poliqueto formador de arrecifes Sabellaria alveolata, el alga coralinal articulada Corallina spp., el alga parda Bifurcaria bifurcata, el alga coralinal incrustante Litophyllum incrustans, el alga roja Chondracanthus acicularis y los caracoles ramoneadores Gibbula spp.) y cuatro taxones de algas más abundantes en verano (el alga parda invasiva Sargassum muticum, el alga verde Ulva spp., el quelpo Laminaria ochroleuca y el alga roja filamentosa Ceramium spp.). Estos datos contribuyen al conocimiento de las comunidades de charcas rocosas intermareales y tienen potenciales implicaciones en los programas de monitorización enfocados a medir las modificaciones ecológicas relacionadas con alteraciones naturales y antropogénicas y son útiles para identificar los procesos responsables de la variabilidad de estas comunidades.

Palabras clave: charcas rocosas, intermareal rocoso, variabilidad estacional, bentos, Sabellaria alveolata, Portugal.

\section{INTRODUCTION}

Investigating patterns of variation in space and time of natural populations and assemblages is a main and challenging goal of ecology (Levin 1992, Underwood et al. 2000). Although there is large and widespread evidence that patterns of distribution, abundance and diversity of organisms are heterogeneous over a range 
of spatial and temporal scales (Underwood et al. 2000, Benedetti-Cecchi 2001, Fraschetti et al. 2005, Terlizzi et al. 2007, Valdivia et al. 2011), this concept is still key for a number of basic and applied ecological issues. As abiotic and biological processes are themselves variable in space and time, examining relevant scales of variation of populations and assemblages is essential to enhance the predictive and explanatory value of ecological models (Andrew and Mapstone 1987, Levin 1992, Underwood and Chapman 1996, Benedetti-Cecchi 2000). Identifying variations of traits of biodiversity over a hierarchy of scales can prevent oversimplified generalizations and clarify how local or current processes can be generalized to larger scales (Underwood and Petraitis 1993, Lawton 1996, Hewitt et al. 1998), support assessments of anthropogenic impacts (e.g. Balestri et al. 2004) and assist the design of management and conservation measures, including the implementation of marine protected areas (e.g. Benedetti-Cecchi et al. 2003). As a consequence, the identification of relevant scales of variation of biological variables has become a legal requirement into management programmes in many countries (e.g. the Water Framework Directive in Europe and the National Environmental Policy Act in the USA).

Tide pools have been reported to be very variable systems at different locations (Metaxas and Scheibling 1993, Metaxas et al. 1994, Underwood and Skilleter 1996, Van Tamelen 1996, Thompson et al. 2002). Tide pools provide peculiar environmental conditions compared with the surrounding rocky habitats, as they are not subject to the tidal cycles of submersion and desiccation of nearby emergent rocky areas. On the other hand, they experience greater fluctuations of physical variables, including temperature, salinity and $\mathrm{pH}$, compared with subtidal habitats, with the occurrence of very harsh conditions particularly at higher levels on the shore (Metaxas and Scheibling 1993). These factors have been invoked to explain the dominance of different groups of macroalgae in pools located at different tidal levels (Dethier 1982, Wolfe and Harlin 1988a, Kooistra et al. 1989, Metaxas et al. 1994) and the reduction of species diversity at increasing heights (Femino and Mathieson 1980, Huggett and Griffiths 1986, Wolfe and Harlin 1988b, Kooistra et al. 1989). Moreover, assemblages are highly variable between pools located at the same height on the shore (Metaxas and Scheibling 1993, Metaxas et al. 1994), probably due to combined abiotic and biological factors. These include physical characteristics, such as size, depth, substratum heterogeneity, orientation and position along the coastline that can provide different microhabitats to different pools (Femino and Mathieson 1980, Metaxas et al. 1994), and biotic factors, such as grazing (Chapman 1990, Benedetti-Cecchi and Cinelli 1995) and competition (Van Tamelen 1996, BenedettiCecchi 2000), often interacting in complex ways (Astles 1993, Dethier 1984, Benedetti-Cecchi and Cinelli 1996, Masterson et al. 2008). This complexity could be responsible for the lower number of studies on pat- terns of distribution and abundance of assemblages in pools compared with other rocky habitats. However, the great variability of this system suggests a limited possibility to generalize to unstudied sets of rock pools the information previously obtained on patterns and their potential driving processes from other pools.

A few studies have described macroalgal assemblages of rock pools on the Portuguese coast. In this region, each of a number of pools sampled along about $60 \mathrm{~km}$ of coast was indicated as being unique in terms of macroalgal assemblages, probably due to biological factors, such as timing of colonization, rather than to physical characteristics of the habitat (Araújo et al. 2006). Moreover, Rubal et al. (2011) documented seasonal patterns of variability of macroalgal assemblages sampled in pools from two sites between $41^{\circ} 02^{\prime} \mathrm{N}$ and $41^{\circ} 09^{\prime} \mathrm{N}$, although this study did not provide any formal test of differences between pools. As in most previous studies that have focused on algal organisms (but see Metaxas and Scheibling 1993), the benthic animal component of Portuguese rock pool assemblages and patterns of temporal (seasonal and within season) and spatial (among and within pools) variability of sessile assemblages from the present location were not taken into account.

The present study was aimed at comparing temporal and spatial patterns of variation of algal and invertebrate assemblages in rock pools located on the Portuguese coast north of Viana do Castelo. The adopted sampling design allowed us to test hypotheses on differences in the structure of whole assemblages, the abundance of individual taxa and the total number of taxa between summer and winter, between dates within each season and between replicate pools. Physical traits, including size, depth and position along the coast of rock pools, were also measured and tested in order to determine whether their possible variation could have potentially affected differences in the structure of assemblages and in the abundance of individual taxa in pools assigned to each date and season of sampling.

\section{MATERIALS AND METHODS}

\section{Study system}

The study was carried out between December 2010 and July 2011 in a total of 40 rock pools located along about $1 \mathrm{~km}$ of coast north of Viana do Castelo (northern Portugal, between $41^{\circ} 42^{\prime} 01^{\prime \prime} \mathrm{N}$ and $41^{\circ} 42^{\prime} 16^{\prime \prime} \mathrm{N}$ ). The tidal regime along the Portuguese coast is semidiurnal, with the largest spring tides of about $4 \mathrm{~m}$, and all pools were at a tidal height of $0.5-1 \mathrm{~m}$ above Chart Datum. In the study area, the summer and winter season are characterized by clear differences in mean air temperature, mean monthly precipitation, light intensity and period, water temperature and hydrodynamic conditions (see Rubal et al. 2011 and references therein for details). Nutrient concentrations are also seasonally variable due to upwelling events that are particularly 
intense from April to September (Lemos and Pires 2004). The coast is north-to-south oriented, exposed to prevailing northwest oceanic swell and characterized by a continuous rocky shore with granite as the typical substratum.

At the examined height on the shore, the emergent rock is dominated by the mussel Mytilus galloprovincialis (Lamarck) and the barnacle Chthamalus stellatus (Poli), while pools host more diversified macroalgal and invertebrate assemblages. Among the most common brown algae are the kelp Laminaria ochroleuca Bachelot de la Pylaie, Bifurcaria bifurcata R. Ross and the invasive Sargassum muticum (Yendo) Fesholt. Red algae typically include Chondracanthus acicularis (Roth) Fredericq, Chondracanthus teedei (Roth) Kützing, encrusting corallines (e.g. Lithophyllum incrustans Philippi), articulated corallines (e.g. Corallina spp. and Jania spp.) and filamentous species (e.g. Ceramium spp.), while common green algae are those of the genus Ulva. The reef-forming polychaete Sabellaria alveolata Linnaeus is the most common sessile invertebrate, while grazers are mostly represented by snails of the genus Gibbula, limpets (Patella spp.) and the sea urchin Paracentrotus lividus Lamarck.

\section{Sampling design and collection of data}

Sampling was repeated on two winter (December 2010 and February 2011) and two summer (June 2011 and July 2011) dates, with an independent set of ten pools assigned at random to each date and interspersed along the study coast. The percentage cover of sessile organisms and the number of individuals of mobile animals were visually estimated in each of three quadrates $(30 \times 30 \mathrm{~cm})$ established at random in each pool. Organisms were identified to the most detailed level of taxonomic resolution achievable in the field. Percentage cover estimates were obtained by dividing each quadrate into 25 sub-quadrates of $6 \times 6 \mathrm{~cm}$, assigning to each taxon a score from 0 (absence of that taxon) to 4 (a whole sub-quadrate covered by that taxon) and adding up the 25 estimates (Dethier et al. 1993). In each case in which a sessile taxon covered less than one sub-quadrate, an arbitrary value of 1 was assigned. The abundance of organisms attached to both primary and secondary substratum were taken into account. This, in addition to the multilayered structure of assemblages, made the total cover in each quadrate exceed $100 \%$ in some cases.

Geographic coordinates of the centre, maximum depth, length, width and size (roughly estimated) were recorded for each pool. The position along the shore was considered relevant due to the south to north orientation of the coastline in the study area and the close presence in the south of the city and port of Viana do Castelo and the estuary of the Lima river. These traits could determine the occurrence of gradients that in theory have different effects on pools located at increasing distances from these sources of physical and chemical disturbance. Pools ranged from $2.5 \mathrm{~m}$ to 7.4 $\mathrm{m}$ in length, from $1.2 \mathrm{~m}$ to $4.8 \mathrm{~m}$ in width, from $0.2 \mathrm{~m}$ to $0.7 \mathrm{~m}$ in depth and from $6.0 \mathrm{~m}^{2}$ to $33 \mathrm{~m}^{2}$ in area.

\section{Data analysis}

Data were analysed with multivariate and univariate techniques to test the hypothesis that the structure of assemblages, the abundance of individual taxa and the total number of taxa differed between seasons, between dates within seasons and between pools. Preliminary analyses of variance (ANOVA), however, were carried out to test for differences between pools assigned to sampling on each date and in each season in the measured physical variables. Each of these was based on a two-way model, including the factors Season (fixed, with two levels: Winter vs Summer) and Date (random, nested in Season, with two levels), with ten replicates (the ten pools assigned to sampling on each date and in each season).

Permutational multivariate analysis of variance (PERMANOVA, Anderson 2001) based on Bray-Curtis untransformed dissimilarities was used to analyse the multivariate assemblage data. The model for this analysis included the three factors Season, Date (the same as for the previously described ANOVAs) and Pool (random, nested in Season and Date, with ten levels), with three replicates (the three quadrates sampled in each pool on each date). When an excessively low number of possible permutations prevented a test with sufficient power from being obtained, a p-value was calculated using 999 Monte Carlo draws from the appropriate asymptotic permutation distribution (Anderson and Robinson 2003). In order to test whether differences of assemblages between pools, dates and seasons were due to differences in multivariate dispersion between groups rather than mostly in the location of centroids, the same model was tested for differences in dispersion by means of the PERMDISP program (Anderson 2006).

Multivariate patterns were illustrated by non-metric multidimensional scaling (nMDS), involving the calculation of centroids of assemblages for each sampled pool. Principal coordinates were calculated from the Bray-Curtis dissimilarity matrix of the whole set of data and centroids were obtained as averages of the principal coordinates over the three replicates in each pool assigned to each date and season of sampling (McArdle and Anderson 2001). Finally, a matrix of Euclidean distances between each pair of centroids was calculated and used as the input for the nMDS.

The SIMPER procedure (Clarke 1993) was used to determine the percentage contribution $\left(\delta_{\mathrm{i}} \%\right)$ of each taxon to the Bray-Curtis dissimilarity between assemblages sampled in winter and summer $\left(\delta_{\mathrm{i}}\right)$. A taxon was considered important if its contribution to total percentage dissimilarity was $\geq 3 \%$. The ratio $\delta_{\mathrm{i}} / \operatorname{SD}\left(\delta_{\mathrm{i}}\right)$ was used to quantify the consistency of the contribution of a particular taxon to the average dissimilarity in all pairwise comparisons of samples between win- 
ter and summer. Values $\geq 1$ indicated a high degree of consistency.

Data on the abundance of relevant (according to the SIMPER results) individual taxa and the total number of identified taxa were analysed with analysis of variance (ANOVA), using the same model as the multivariate case described above.

Before each ANOVA, Cochran's $C$ tests were done to check for homogeneity of variances. When possible, data were log-transformed to remove the heterogeneity of variances. When this was not possible, untransformed data were analysed and results were considered robust if not significant (at $\mathrm{p}>0.05$ ) or significant at $\mathrm{p}<0.01$ (to compensate for the increased probability of type I error, Underwood 1997).

\section{RESULTS}

\section{Physical traits}

The ANOVA indicated that the ten replicate pools assigned to sampling on each date and in each season did not differ statistically for the position along the shore (season: $\mathrm{MS}=396.9, F_{1,2}=0.03, \mathrm{p}>0.8$; date: $\mathrm{MS}=15852.8, F_{2,36}=0.26, \mathrm{p}>0.7$ ), the depth (season: $\mathrm{MS}=9.0, F_{1,2}=0.20, \mathrm{p}>0.6$; date: $\mathrm{MS}=44.4, F_{2,36}=0.27$, $\mathrm{p}>0.7$ or the size (season: $\mathrm{MS}=139.3, F_{1,2}=1.21, \mathrm{p}>0.3$; date: $\left.\mathrm{MS}=115.3, F_{2,36}=1.19, \mathrm{p}>0.3\right)$.

\section{Structure of assemblages}

A total of 62 taxa, including 49 macroalgae and 13 invertebrates, were identified. The PERMANOVA analysis revealed significant seasonal differences in the structure of assemblages, not masked by the great variability between dates and between pools (Table 1) and clearly illustrated by the sharp separation of centroids of pools sampled in winter from those of pools sampled in summer (Fig. 1). The PERMDISP analysis, however, indicated that differences between seasons, as well as those between dates and between pools, were actually due to differences in the locations of centroids rather than in their dispersion $\left(F_{\text {Season }}=3.36, \mathrm{p}=0.09\right.$; $\left.F_{\text {Date }}=0.62, \mathrm{p}=0.44 ; F_{\text {Pool }}=1.59, \mathrm{p}=0.21\right)$.

SIMPER analysis indicated 10 (8 macroalgal and 2 animal) taxa as important (i.e. contributing to $\geq 3 \%$ of percentage dissimilarity) in discriminating between winter and summer. Collectively, these taxa contributed more than $83 \%$ to the total dissimilarity (Table 2). The contribution of Sabellaria alveolata, Corallina

TABLE 1. - Permutational multivariate analysis of variance (PERMANOVA) on rock pool assemblages. Significant effects are indicated in bold. $\mathrm{P}(\mathrm{MC})=\mathrm{p}$-value calculated by Monte Carlo method.

\begin{tabular}{lcccccc}
\hline $\begin{array}{l}\text { Source of } \\
\text { variation }\end{array}$ & df & MS pseudo- $F$ & $\mathrm{p}$ & $\mathrm{p}(\mathrm{MC}) \begin{array}{l}\text { Permutable units } \\
\text { and denominator }\end{array}$ \\
\hline Season=S & 1 & 58926.8 & 6.8 & 0.315 & $\mathbf{0 . 0 0 2}$ & 4 Date $(\mathrm{S})$ cells \\
Date $(\mathrm{S})=\mathrm{D}(\mathrm{S})$ & 2 & 8625.3 & 2.3 & $\mathbf{0 . 0 1 1}$ & & 40 Pool $(\mathrm{D}(\mathrm{S})$ cells \\
Pool $(\mathrm{D}(\mathrm{S}))$ & 36 & 3824.1 & 3.5 & $\mathbf{0 . 0 0 1}$ & & 120 Raw units \\
Residual & 80 & 1097.2 & & & & \\
\hline
\end{tabular}

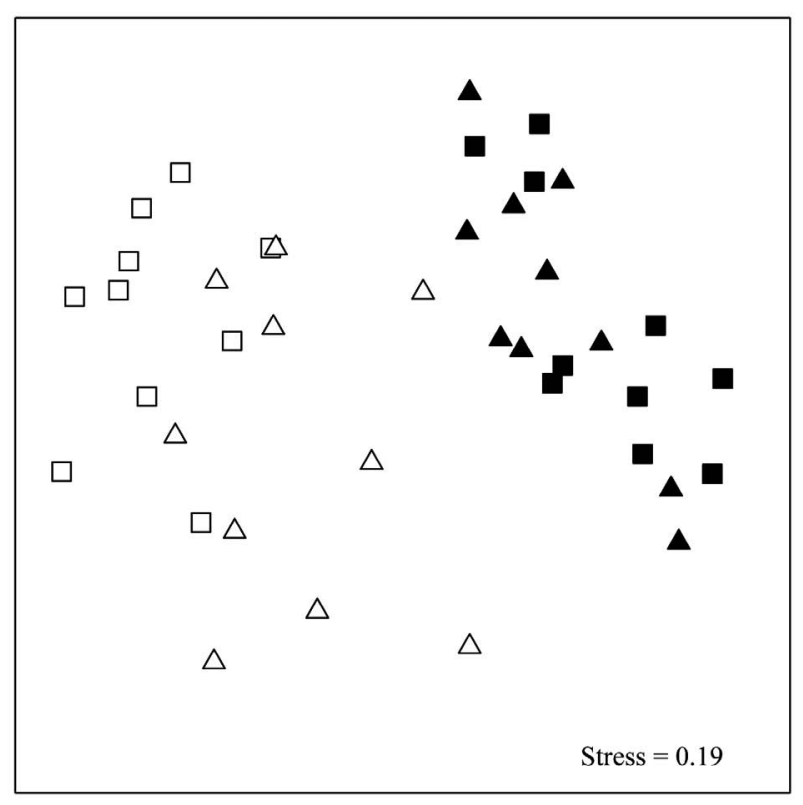

FIG. 1. - nMDS plots of centroids of pools sampled in winter (black) and summer (white), at two dates in each season. Date 1=December 2010 (Winter: full square) and Jun 2011 (Summer: full triangle), Date 2=February 2011 (Winter: open square) and July 2011 (Summer: open triangle).

spp. and Ulva spp. to percentage dissimilarities was highly consistent among pairwise comparisons of samples between the two groups (Table 2).

\section{Individual taxa and total number of taxa}

Among the important individual taxa identified by SIMPER, Sabellaria alveolata (Fig. 2A), Corallina spp. (Fig. 2B), Bifurcaria bifurcata (Fig. 2G), Lithophyllum incrustans (Fig. 2H), Chondracanthus acicularis (Fig. 2I) and Gibbula spp. (Fig. 2J) were more abundant in winter than in summer. The opposite pattern between seasons was shown by Sargassum muticum (Fig. 2C), Ulva spp. (Fig. 2D), Laminaria ochroleuca (Fig. 2E) and Ceramium spp. (Fig. 2F). The analysis of $S$. alveolata, S. muticum, L. ochroleuca and

TABle 2. - Contribution $\left(\delta_{i}\right)$ of individual taxa from rock pool assemblages to the average Bray-Curtis dissimilarity between winter (W) and summer (S). Only taxa contributing $\geq 3 \%$ of percentage dissimilarity are included. Values of $\delta_{i} / \mathrm{SD}\left(\delta_{i}\right) \geq 1$ indicate that the contribution of a taxon to percentage dissimilarity was consistent among pairwise comparisons of samples between winter and summer.

\begin{tabular}{|c|c|c|c|c|c|}
\hline Taxon & $\begin{array}{c}\text { erage } \\
\text { W }\end{array}$ & $\begin{array}{l}\text { S } \\
\text { S }\end{array}$ & e $\delta_{i}$ & $\delta_{i} \%$ & $\delta_{i} / \mathrm{SD}\left(\delta_{i}\right)$ \\
\hline Sabellaria alveolata & 36.1 & 5.0 & 13.5 & 17.7 & 1.1 \\
\hline Corallina spp. & 38.3 & 22.4 & 11.6 & 15.2 & 1.4 \\
\hline Sargassum muticum & 7.0 & 26.5 & 10.5 & 13.7 & 0.9 \\
\hline Ulva spp. & 0.4 & 20.4 & 9.2 & 12.0 & 1.3 \\
\hline Laminaria ochroleuca & 3.4 & 8.5 & 4.1 & 5.4 & 0.7 \\
\hline Ceramium spp. & 0.0 & 8.5 & 3.9 & 5.2 & 0.8 \\
\hline Bifurcaria bifurcata & 7.6 & 1.7 & 3.4 & 4.4 & 0.7 \\
\hline Lithophyllum incrustans & 5.8 & 2.7 & 2.9 & 3.7 & 0.8 \\
\hline Chondracanthus acicularis & 4.6 & 1.7 & 2.4 & 3.1 & 0.7 \\
\hline Gibbula spp. & 6.3 & 2.0 & 2.2 & 3.0 & 0.9 \\
\hline
\end{tabular}




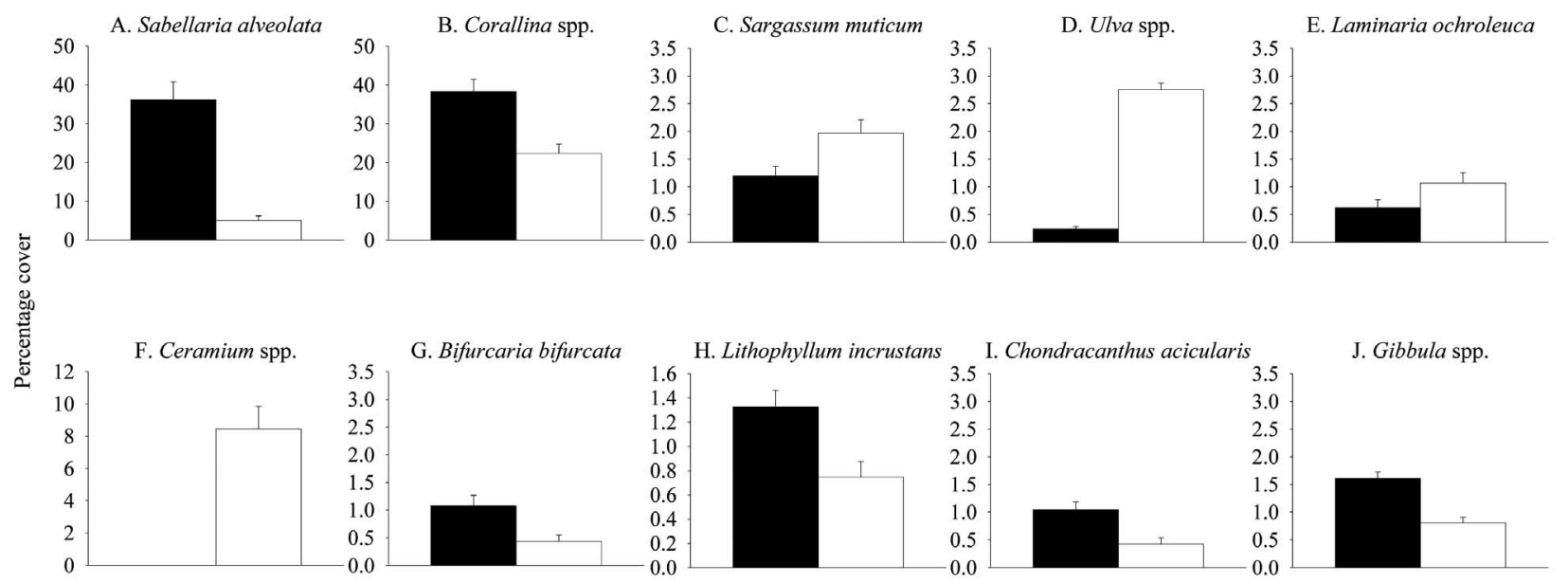

FIG. 2. - Mean (+SE) percentage cover of individual taxa (A, B and F: untransformed data; C, D, E, G, H, I and J: log-transformed data) in winter (black) and summer (white). Data averaged over three replicate quadrates, ten pools and two dates.

TABLE 3. - Summary of ANOVAs for individual taxa from rock pool assemblages. $* \mathrm{p}<0.05 ; * * \mathrm{p}<0.01$, *** $\mathrm{p}<0.001$.

\begin{tabular}{|c|c|c|c|c|c|c|c|c|c|c|c|c|c|}
\hline \multirow[b]{2}{*}{ Source of variation } & \multirow[b]{2}{*}{$\mathrm{df}$} & \multicolumn{2}{|c|}{$\begin{array}{c}\text { Sabellaria } \\
\text { alveolata }\end{array}$} & \multicolumn{2}{|c|}{$\begin{array}{l}\text { Corallina } \\
\text { spp. }\end{array}$} & \multicolumn{2}{|c|}{$\begin{array}{l}\text { Sargassum } \\
\text { muticum }\end{array}$} & \multicolumn{2}{|c|}{$\begin{array}{l}\text { Ulva } \\
\text { spp. }\end{array}$} & \multicolumn{2}{|c|}{$\begin{array}{l}\text { Laminaria } \\
\text { ochroleuca }\end{array}$} & \multicolumn{2}{|c|}{$\begin{array}{l}\text { Ceramium } \\
\text { spp. }\end{array}$} \\
\hline & & MS & $F$ & MS & $F$ & MS & $F$ & MS & $F$ & MS & $F$ & MS & $F$ \\
\hline Season $=\mathrm{S}$ & 1 & 28985.2 & 6.2 & 7648.0 & $90.7 *$ & 17.9 & 1.6 & 189.8 & $103.8 * *$ & 6.0 & 3.2 & 2142.1 & 5.3 \\
\hline $\operatorname{Date}(S)=D(S)$ & 2 & 4688.2 & 3.1 & 84.3 & 0.1 & 11.4 & 2.6 & 1.8 & 2.2 & 1.8 & 0.6 & 407.0 & 3.3 \\
\hline $\operatorname{Pool}(\mathrm{D}(\mathrm{S}))$ & 36 & 1511.5 & $6.1 * * *$ & $=1049.0$ & $5.0 * * *$ & 4.5 & $3.0 * * *$ & 0.8 & $2.8 * * *$ & 2.9 & $2.6 * * *$ & 125.1 & $6.8 * * *$ \\
\hline Residual & 80 & 249.1 & & & 211.5 & & & 1.5 & & 0.3 & 1.1 & & 18.4 \\
\hline Cochran's test & & $C=0.296^{* *}$ & & $C=0.08$ & & $C=0.119$ & & $C=0.119$ & & $C=0.112$ & & $C=0.321$ & \\
\hline Transformation & & None & & None & & $\operatorname{Ln}(x+1)$ & & $\operatorname{Ln}(x+1)$ & & $\operatorname{Ln}(x+1)$ & & None & \\
\hline
\end{tabular}

TABLE 4. - Summary of ANOVAs for individual taxa and the total number of taxa from rock pool assemblages. * $\mathrm{p}<0.05 ; * * \mathrm{p}<0.01, * * *$ $\mathrm{p}<0.001$.

\begin{tabular}{|c|c|c|c|c|c|c|c|c|c|c|c|}
\hline \multirow[b]{2}{*}{ Source of variation } & \multirow[b]{2}{*}{ df } & \multicolumn{2}{|c|}{$\begin{array}{l}\text { Bifurcaria } \\
\text { bifurcata }\end{array}$} & \multicolumn{2}{|c|}{$\begin{array}{l}\text { Lithophyllum } \\
\text { incrustans }\end{array}$} & \multicolumn{2}{|c|}{$\begin{array}{c}\text { Chondracanthus } \\
\text { acicularis }\end{array}$} & \multicolumn{2}{|c|}{$\begin{array}{l}\text { Gibbula } \\
\text { spp. }\end{array}$} & \multicolumn{2}{|c|}{$\begin{array}{l}\text { Total } \\
\text { taxa }\end{array}$} \\
\hline & & MS & $F$ & MS & $F$ & MS & $F$ & MS & $F$ & MS & $F$ \\
\hline Season $=S$ & 1 & 12.5 & $40.5^{*}$ & 10.1 & $3608.5 * * *$ & 11.6 & $75.6^{*}$ & 19.4 & $21.6^{*}$ & 4.0 & 0.1 \\
\hline $\operatorname{Date}(S)=D(S)$ & 2 & 0.3 & 0.1 & 0.0 & 0.0 & 0.2 & 0.1 & 0.9 & 0.9 & 75.1 & $7.3^{* *}$ \\
\hline $\operatorname{Pool}(\mathrm{D}(\mathrm{S}))$ & 36 & 2.5 & $2.9 * * *$ & 1.4 & 1.5 & 2.0 & $3.7 * * *$ & 1.1 & $2.2^{* *}$ & 10.3 & $2.8 * * *$ \\
\hline Residual & 80 & 0.9 & & 0.9 & & 0.5 & & 0.5 & & 3.7 & \\
\hline Cochran's test & & $C=0.091$ & & $C=0.08$ & & $C=0.151$ & & $C=0.097$ & & $C=0.089$ & \\
\hline Transformation & & $\operatorname{Ln}(x+1)$ & & $\operatorname{Ln}(x+1)$ & & $\operatorname{Ln}(x+1)$ & & $\operatorname{Ln}(x+1)$ & & None & \\
\hline
\end{tabular}

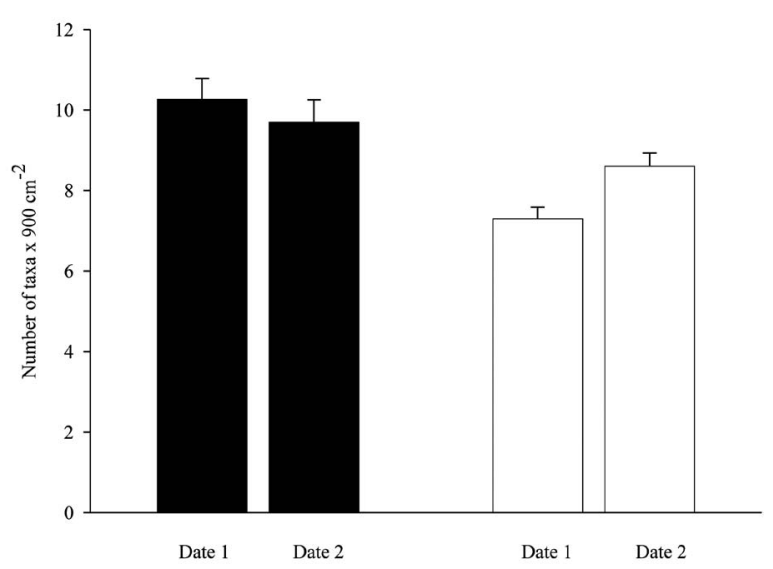

FIG. 3. - Mean (+SE) number of taxa sampled at each of two winter (black) and summer (white) dates. Data averaged over three replicate quadrates and ten pools.
Ceramium spp., however, detected no significant effect of Season, probably due to the low power of the test and the masking effect of the great variability between pools in the abundance of almost all response variables (Tables 3 and 4).

The total number of taxa did not differ between winter and summer, but significant variations were detected between dates within each season (Table 4, Fig. 3). Analogously to all other multivariate and univariate patterns, a large variability between pools was also detected for this response variable (Table 4).

\section{DISCUSSION}

The present study documented differences between winter and summer in the structure of algal and invertebrate assemblages. This is in agreement with find- 
ings on macroalgal assemblages of rock pools from other locations in the same geographical area (Rubal et al. 2011). Here, however, seasonal differences were mainly driven by an invertebrate species, the polychaete Sabellaria alveolata, which was more abundant in winter than in summer. This species is responsible for the construction of the largest biogenic reefs in Europe, providing a highly dynamic habitat for diversified associated organisms (Dubois et al. 2002, Fournier et al. 2010). Sabellaria alveolata reefs were indicated as extremely sensitive to the mechanical impact of natural (e.g. storms) or anthropogenic (e.g. trampling) disturbances, which can damage the existing bioconstructions and reduce the density of new recruits (Dubois et al. 2002, 2006). On the studied shore, mechanical impacts from waves and trampling have clear seasonal patterns related to the occurrence of extreme storms, mostly in winter (Dias et al. 2002) and human frequentation of the shore, which is particularly intense in summer (Araújo et al. 2009). As extreme waves could directly cause seasonal differences in the abundance of $S$. alveolata that are opposite to the present patterns and trampling might drastically affect intertidal assemblages on emergent rock rather than in rock pools, both mechanisms are unlikely to provide convincing explanations to our findings. It is worth noting, however, that present bioconstructions of S. alveolata are not in the form of reefs, but rather of encrusting colonies adhering to the rock, for whose dynamics other processes might be relevant. Among these, a key role might be played by the availability of sediment in the water column, on which $S$. alveolata depends for its bioconstructions (e.g. Desroy et al. 2011). No data on sediments were collected in the present study, but it could be logically assumed that the greater intensity of precipitations in winter (Dias et al. 2002) might cause a larger input of terrigenous sediments on the shore. This input might have caused favourable conditions for the development of larger covers of encrusting S. alveolata in winter than in summer. In summer, instead, the established colonies could have suffered the negative effects of even relatively mild disturbances, such as waves and trampling, not counteracted by large amounts of available sediments. Alternatively, but not mutually exclusively, seasonal patterns in the abundance of $S$. alveolata could have been driven by differential hydrodynamic patterns affecting the distribution of larvae of this species in the water and their possibilities of settling. Laboratory studies have indicated that the larval life of S. alveolata can last several months (Wilson 1970). Although this period is likely shorter under natural conditions and spawning of $S$. alveolata in the NE Atlantic has been indicated to occur mostly between April and October (e.g. Dubois et al. 2007), planktonic larvae of this species could have been present in the study area in both winter and summer. During winter months, the main currents on the Portuguese coast flow northward, while a prevailing flow in the opposite direction occurs during the summer (Coelho et al. 2002, Huthance et al. 2002).
We cannot hypothesize how this hydrodynamic process could have worked in detail, but in principle it might have caused a larger transportation of larvae, and thus a larger settlement and development of S. alveolata colonies, from southern locations where this species is particularly abundant (e,g, the Belinho area located about $10 \mathrm{~km}$ apart from the study site, unpublished data) to rock pools in winter than in summer. Laboratory studies (e.g. Ayata et al. 2009) have indicated that the hydrodynamic regime is essential for the success of dispersal and settlement of larvae and for the growth of adults of $S$. alveolata, probably by affecting connectivity among populations (Caley et al. 1996) or through the transportation of sediments with a grain size and shape that are more suitable for their bioconstructions (Godet et al. 2011).

Articulated algae of the genus Corallina were also more abundant in pools sampled in winter than in summer. Drastic reductions of intertidal populations of Corallina elongata during summer months were documented in the Strait of Gibraltar (Guerra-García et al. 2011), and peaks in abundance during late autumnwinter were shown by geniculate coralline algae in rock pools from the Azores (Neto 2000) and the NW Mediterranean Sea (Benedetti-Cecchi and Cinelli 1994). These seasonal fluctuations could be explained by the sensitivity of these algae to stressful environmental conditions occurring during summer, including high temperatures and osmotic stress (Davison and Pearson 1996, Guerra-García et al. 2010), while their calcified thallus is able to resist under strong wave action and abrasion, typically occurring during the winter (Littler and Kauker 1984). In addition, articulated coralline algae can regenerate quickly from their persistent basal crust (Littler and Kauker 1984, Konar and Foster 1992), a trait that could have favoured them over potentially better competitors in disturbed patches created by winter storms (e.g. Benedetti-Cecchi et al. 1996).

Although with less overall covers, other macroalgal species with very different life histories showed greater abundances in winter than in summer. For the brown Bifurcaria bifurcata and the red Chondracanthus acicularis, a possible explanation could involve the negative effect of competing species. It has been indicated, for instance, that the abundance of B. bifurcata is drastically reduced in the presence of large covers of the invasive seaweed Sargassum muticum (Viejo 1997, Sánchez et al. 2005), most likely due to the light reduction occurring under the $S$. muticum canopy (Britton-Simmons 2004), while negative effects of this invader on native macroalgae could be negligible when its abundance is low (Arenas and Fernández 2000, Sánchez and Fernández 2005). The increase in abundance of $S$. muticum in summer compared with winter might therefore have played a role in maintaining corresponding variations in the abundance of the native $B$. bifurcata and $C$. acicularis in our rock pools. Further support to this model could come from the observation that increases in cover of northeast Atlantic 
C. acicularis populations are likely due to vegetative propagation (Guiry and Cunningham 1984), a process whose success would be inversely related to the preemption of the substratum by $S$. muticum. Interactions of abiotic and biological factors, instead, might explain seasonal patterns of Lithophyllum incrustans. Encrusting coralline algae were described as poor competitors for space (Breitburg 1984), but their morphology and life traits make them very resistant to physical disturbance. They thus tend to dominate in rocky habitats exposed to severe abiotic stress, including the mechanical impact of waves (e.g. Bertocci et al. 2005), and to intense grazing that can remove potential algal competitors (Steneck 1986, Airoldi 2000, Bulleri et al. 2002). As stated above, such favourable abiotic conditions, normally occurring at the study site during the winter might have contributed to present findings on L. incrustans. Further supporting seasonal variations in the abundance of grazers, such as limpets and sea urchins (e.g. Bulleri et al. 2002 and references therein), usually responsible for the maintenance of barren habitats dominated by encrusting corallines, were not found in the present study. The greater abundance of grazing gastropods Gibbula spp. sampled in winter than in summer and the opposite pattern of ephemeral algae such as Ulva spp. and Ceramium spp., however, were consistent with this model. On the other hand, it is unlikely that the larger cover of $L$. incrustans during the winter was just the result of some sampling artefact due to the reduced secondary cover of canopy-forming species, such as Sargassum muticum and Laminaria ochroleuca, allowing a better estimation of understory encrusting organisms. The low cover of these species ( $7 \%$ and $3.4 \%$ on average, respectively) prevented the occurrence of such a mechanism.

According to previous findings, environmental factors such as light (Cheshire et al. 1996, Golléty et al. 2008) and nutrient availability (e.g. Masterson et al. 2008) can directly control the productivity of several intertidal algae and of Ulva spp. in particular. Solar irradiation and concentrations of nutrients in the water due to upwelling events were reported as greater in summer than in winter months in the study area (Lemos and Pires 2004). Under such conditions, adding to their large ability to reproduce and propagate through spores, zygotes and vegetative fragments (Burrows 1991), species of the genus Ulva may have quickly reached their maximum abundances, occupying the substratum to the detriment of other algal species (e.g. Guimaraens and Coutinho 2000). The availability of nutrients, adding to reduced pressure by grazers, could also explain the presence of Ceramium spp. in summer samples only, as there is evidence that these species can increase in abundance when grazing control is relaxed (Masterson et al. 2008) and can become P-limited in the periods of the year when the water concentration of nutrients is lower (Pedersen et al. 2010).

Present seasonal variations in the abundance of S. muticum are consistent with previous observations of its fast spring growth, early summer reproduction and late summer senescence (Arenas et al. 1995, Arenas and Fernández 2000). Although this species can dominate rock pool assemblages throughout the year (e.g. Baer and Stengel 2010), a key factor driving this seasonal pattern seems to be intraspecific competition under crowded conditions, such as in periods of fast growth (Arenas and Fernández 2000, Arenas et al. 2002; Steen 2003).

The greater abundance of the perennial kelp species Laminaria ochroleuca in summer than in winter can be interpreted mainly as a result of seasonal changes in abiotic variables, primarily the temperature. In fact, L. ochroleuca is considered the only warm-temperate species within the digitate group of the genus Laminaria (tom Dieck 1992) and it has been indicated that its maximum percentages of germination, reproductive success and growth rates occur under ranges of temperature corresponding to those documented for the summer period in the study area (Izquierdo et al. 2002, Rubal et al. 2011). Conversely, its failure in reproduction and drastically reduced growth at temperatures around $10^{\circ} \mathrm{C}$ would make this species less competitive in winter (Izquierdo et al. 2002).

Finally, although unable to mask differences between seasons, present findings indicated a large variability between pools in the structure of assemblages, analogously to previous studies (Metaxas et al. 1994, Araújo et al. 2006). Such variability is often attributed to physical characteristics of each pool. Here, however, spatial and temporal differences were unlikely to be affected by physical traits that are usually considered as particularly important, such as size, depth and position (Femino and Mathieson 1980, Wolfe and Harlin 1988b, Metaxas et al. 1994, Araújo et al. 2006), as these were comparable between pools assigned to each date and season. Other single or interacting abiotic and biological factors, such as the heterogeneity of the substratum, grazing and patchy algal recruitment and colonization, could thus make a larger contribution to driving the variability of assemblages between pools (Menge et al. 1983, Reed et al. 1988, Benedetti-Cecchi and Cinelli 1992, 1995).

The present documentation of the importance of invertebrate taxa and of seasonal and between-pool patterns of distribution of assemblages from areas where such issues had never been addressed before adds new data to the knowledge of the great variability of rock pool systems, with important implications. First, when integrated into longer-term and larger-scale monitoring programmes of coastal assemblages, such data can help to identify ecological modifications related to natural and anthropogenic disturbances (Roberts et al. 1998, Díez et al. 2009). Second, they provide a required basis for identifying and testing the effects of processes responsible for the great variability of assemblages in these rock pools, as even generalizations of findings from apparently similar or nearby systems would be difficult. 


\section{ACKNOWLEDGEMENTS}

This study is part of the project "RAP - Responses to Anthropogenic Perturbations: climatic and nutrient effects on rock pool assemblages" (PTDC/ MAR/111223/2009) funded by the Portuguese FCT Fundação para a Ciência e a Tecnologia, co-funded by FEDER through the programme POFC - COMPETE of QREN. I.B. was supported by FCT within the Programa Ciência 2008 - Fundo Social Europeu. We thank M.J. Anderson for statistical advice, two anonymous reviewers for valuable comments which improved the quality of the manuscript and R. Dominguez for translating to Spanish.

\section{REFERENCES}

Airoldi L. 2000. Responses of algae with different life histories to temporal and spatial variability of disturbance in subtidal reefs. Mar. Ecol. Prog. Ser. 195: 81-92.

Anderson M.J. 2001. A new method for non-parametric multivariate analysis of variance. Austral. Ecol. 26: 32-46.

Anderson M.J. 2006. Distance-based tests for homogeneity of multivariate dispersions. Biometrics 62: 245-253.

Anderson M.J., Robinson J. 2003. Generalized discriminant analysis based on distances. Aust. N.Z. J. Stat. 45: 301-318.

Andrew N.L., Mapstone B.D. 1987. Sampling and the description of spatial pattern in marine ecology. Oceanogr. Mar. Biol. Аnпи. Rev. 52: 39-90.

Araújo R., Sousa-Pinto I., Bárbara I., Quintino V. 2006. Macroalgal communities of intertidal rock pools in the northwest coast of Portugal. Acta Oecol. 30: 192-202.

Araújo R., Vaselli S., Almeida M., Serrão E., Sousa-Pinto I. 2009. Effects of disturbance on marginal populations: human trampling on Ascophyllum nodosum assemblages at its southern distribution limit. Mar. Ecol. Prog. Ser. 378: 81-92.

Arenas F., Fernández C. 2000. Size structure and dynamics in a population of Sargassum muticum (Phaeophyceae). J. Phycol. 36: 1012-1020

Arenas F., Fernández C., Rico J.M., Fernández E., Haya D. 1995. Growth and reproductive strategies of Sargassum muticum Yendo (Fensholt) and Cystoseira nodicaulis (Whit.) Roberts. Sci. Mar. 59: 1-8.

Arenas F., Viejo R.M., Fernández C. 2002. Density-dependent regulation in an invasive seaweed: responses at plant and modular levels. J. Ecol. 90: 820-829.

Astles K.L. 1993. Patterns of abundance and distribution of species in intertidal rock pools. J. Mar. Biol. Assoc. U.K. 73: 555-569.

Ayata S.D., Ellien C., Dumas F., Dubois S., Thiébaut E. 2009. Modelling larval dispersal and settlement of the reef-building polychaete Sabellaria alveolata: role of hydroclimatic processes on the sustainability of biogenic reefs. Contin. Shelf Res. 29: $1605-1623$

Baer J., Stengel D.B. 2010. Variability in growth, development and reproduction of the non-native seaweed Sargassum muticum (Phaeophyceae) on the Irish west coast. Estuar. Coast. Shelf Sci. 90: 185-194.

Balestri E., Benedetti-Cecchi L., Lardicci C. 2004. Variability in patterns of growth and morphology of Posidonia oceanica exposed to urban and industrial wastes: contrasts with two reference locations. J. Exp. Mar. Biol. Ecol. 308: 1-21.

Benedetti-Cecchi L. 2000. Priority effects, taxonomic resolution, and the prediction of variable patterns of colonisation of algae in littoral rock pools. Oecologia 123: 265-274.

Benedetti-Cecchi L. 2001. Variability in abundance of algae and invertebrates at different spatial scales on rocky sea shores. Mar. Ecol. Prog. Ser. 215: 79-92.

Benedetti-Cecchi L., Cinelli F. 1992. Effects of canopy cover, herbivores and substratum type on patterns of Cystoseira spp. settlement and recruitment in littoral rockpools. Mar. Ecol. Prog. Ser. 90: 183-191.
Benedetti-Cecchi L., Cinelli F. 1994. Recovery of patches in an assemblage of geniculate coralline algae: variability at different successional stages. Mar. Ecol. Prog. Ser. 110: 9-18.

Benedetti-Cecchi L., Cinelli F. 1995. Habitat heterogeneity, sea urchin grazing and the distribution of algae in littoral rock pools on the west coast of Italy (western Mediterranean). Mar. Ecol. Prog. Ser. 126: 203-212.

Benedetti-Cecchi L., Cinelli F. 1996. Patterns of disturbance and recovery in littoral rock pools: nonhierarchical competition and spatial variability in secondary succession. Mar. Ecol. Prog. Ser. 135: 145-161.

Benedetti-Cecchi L., Nuti S., Cinelli F. 1996. Analysis of spatial and temporal variability in interactions among algae, limpets and mussels in low-shore habitats on the west coast of Italy. Mar. Ecol. Prog. Ser. 144: 87-96.

Benedetti-Cecchi L., Bertocci I., Micheli F., Maggi E., Fosella T., Vaselli S. 2003. Implications of spatial heterogeneity for management of marine protected areas (MPAs): examples from assemblages of rocky coasts in the northwest Mediterranean. Mar. Env. Res. 55: 429-458.

Bertocci I., Maggi E., Vaselli S., Benedetti-Cecchi L. 2005. Contrasting effects of mean intensity and temporal variation of disturbance on assemblages of rocky shores. Ecology 86: 2061-2067.

Breitburg D.L. 1984. Residual effects of grazing: inhibition of competitor recruitment by encrusting coralline algae. Ecology 65 : 1136-1143.

Britton-Simmons K.H. 2004. Direct and indirect effects of the introduced alga Sargassum muticum on benthic subtidal communities of Washington State, USA. Mar. Ecol. Prog. Ser. 277: 61-78.

Bulleri F., Bertocci I., Micheli F. 2002. Interplay of encrusting coralline algae and sea urchins in maintaining alternative habitats. Mar. Ecol. Prog. Ser. 243: 101-109.

Caley M., Carr M., Hixon M.A., Hughes T.P., Jones G.P, Menge B.A. 1996. Recruitment and the local dynamics of open marine populations. Annu. Rev. Ecol. Syst. 27: 477-500.

Chapman A.R.O. 1990. Effects of grazing, canopy cover and substratum type on the abundances of common species of seaweeds inhabiting littoral fringe tide pools. Bot. Mar. 33: 319-326.

Cheshire A.C., Westphalen G., Wenden A., Scriven L.J., Rowland B.C. 1996. Photosynthesis and respiration of phaeophyceandominated macroalgal communities in summer and winter. Aquat. Bot. 55: 159-170.

Clarke K.R. 1993. Nonparametric multivariate analyses of changes in community structure. Austral. J. Ecol. 18: 117-143.

Coelho H.S., Neves R.J.J., White M., Leitão P.C., Santos A.J. 2002. A model for ocean circulation on the Iberian coast. J. Mar. Syst. 32: $153-179$

Davison I.R., Pearson G.A. 1996. Stress tolerance in intertidal seaweeds. J. Phycol. 32: 197-211.

Desroy N., Dubois S.F., Fournier J., Ricquiers L., Le Mao P., Guerin L., Gerla D., Rougerie M., Legendre A. 2011. The conservation status of Sabellaria alveolata (L.) (Polychaeta: Sabellariidae) reefs in the Bay of Mont-Saint-Michel. Aquat. Conserv.: Mar. Freshwat. Ecosyst. 21: 462-471.

Dethier M.N. 1982. Pattern and process in tidepool algae: factors influencing seasonality and distribution. Bot. Mar. 25: 55-66.

Dethier M.N. 1984. Disturbance and recovery in intertidal pools: maintenance of mosaic patterns. Ecol. Monogr. 54: 99-118.

Dethier M.N., Graham E.S., Cohen S., Tear L.M. 1993. Visual versus random-point percent cover estimations: "objective" is not always better. Mar. Ecol. Prog. Ser. 96: 93-100.

Dias J.M.A., Gonzalez R., Garcia C., Diaz-del Rio V. 2002. Sediment distribution patterns on the Galicia-Minho continental shelf. Prog. Oceanogr. 52: 215-231.

Díez I., Santolaria A., Secilla A., Gorostiaga J.M. 2009. Recovery stages over long- term monitoring of the intertidal vegetation in the Abra de Bilbao area and on the adjacent coast (N. Spain). Eur. J. Phycol. 4: 1-14.

Dubois S., Retière C., Olivier F. 2002. Biodiversity associated with Sabellaria alveolata (Polychaeta: Sabellariidae) reefs: effects of human disturbances. J. Mar. Biol. Assoc. U.K. 82: 817-826.

Dubois S., Commito J.A., Olivier F., Retière C. 2006. Effects of epibionts on Sabellaria alveolata (L.) biogenic reefs and their associated fauna in the Bay of Mont Saint-Michel. Estuar. Coast. Shelf Sci. 68: 635-646.

Dubois S., Comtet T., Retière C., Thiébaut E. 2007. Distribution 
and retention of Sabellaria alveolata larvae (Polychaeta: Sabellariidae) in the Bay of Mont-Saint-Michel, France. Mar. Ecol. Prog. Ser. 344: 15-28.

Femino R., Mathieson A. 1980. Investigations of New England marine algae IV. The ecology and seasonal succession of tide pool algae at Bald Head Cliff, York, Maine, USA. Bot. Mar. 23: $319-332$

Fournier J., Etienne S., Le Cam J.B. 2010. Inter- and intraspecific variability in the chemical composition of the mineral phase of cements from several tube-building polychaetes. Geobios 43 : 191-200.

Fraschetti S., Terlizzi A., Benedetti-Cecchi L. 2005. Patterns of distribution of marine assemblages from rocky shores: evidence of relevant scales of variation. Mar. Ecol. Prog. Ser. 296: 13-29.

Godet L., Fournier J., Jaffré M., Desroy N. 2011. Influence of stability and fragmentation of a worm-reef on benthic macrofauna. Estuar. Coast. Shelf Sci. 92: 472-479.

Golléty C., Migné A., Davoult D. 2008. Benthic metabolism on a sheltered rocky shore: role of the canopy in the carbon budget. J. Phycol. 44: 1146-1153.

Guerra-García J.M., Cabezas M.P., Baeza-Rojano E., GarcíaGómez J.C. 2011. Spatial patterns and seasonal fluctuations of intertidal macroalgal assemblages from Tarifa Island, southern Spain: relationship with associated Crustacea. J. Mar. Biol. Assoc. U.K. 91: 107-116.

Guimaraens M.A., Coutinho R. 2000. Temporal and spatial variation of Ulva spp. And water properties in the Cabo Frio upwelling region of Brazil. Aquat. Bot. 66: 101-114.

Guiry M.D., Cunningham E.M. 1984. Photoperiodic and temperature responses in the reproduction of north-eastern Atlantic Gigartina acicularis (Rhodophyta: Gigartinales). Phycologia 23: 357-367.

Hewitt J.E., Thrush S.F., Cummings V.J., Turner S.J. 1998. The effect of changing sampling scales on our ability to detect effects of large-scale processes on communities. J. Exp. Mar. Biol. Ecol. 227: 251-264

Huggett J., Griffiths C.L. 1986. Some relationships between elevation, physico-chemical variables and biota of intertidal rock pools. Mar. Ecol. Prog. Ser. 29: 189-197.

Huthnance J.M., Van Aken H.M., White M., Barton E.D., LeCann B., Coelho E.F., Fanjul E.A., Miller P., Vitorino J. 2002 Ocean margin exchange-water flux estimates. J. Mar. Syst. 32: $107-137$.

Izquierdo J.L., Pérez-Ruzafa I.M., Gallardo T. 2002. Effect of temperature and photon fluence rate on gametophytes and young sporophytes of Laminaria ochroleuca Pylaie. Helgoland Mar. Res. 55: 285-292

Konar B., Foster M.S. 1992. Distribution and recruitment of subtidal geniculate coralline algae. J. Phycol. 28: 273-280.

Kooistra W.H.C.F., Joosten A.M.T., van den Hoek C. 1989. Zonation patterns in intertidal pools and their possible causes: multivariate approach. Bot. Mar. 32: 9-26.

Lawton J.H. 1996. Patterns in ecology. Oikos 75: 145-147.

Lemos R.T., Pires H.O. 2004. The upwelling regime off the west Portuguese coast, 1941-2000. Int. J. Climat. 24: 511-524.

Levin S.A. 1992. The problem of pattern and scale in ecology. Ecology 73: 1943-1967.

Littler M.M., Kauker B.J. 1984. Heterotrichy and survival strategies in the red alga Corallina officinalis L. Bot. Mar. 27: 37-44.

Masterson P., Arenas F.A., Thompson R.C., Jenkins S.R. 2008. Interaction of top down and bottom up factors in intertidal rockpools: Effects on early successional macroalgal community composition, abundance and productivity. J. Exp. Mar. Biol. Ecol. 363: 12-20.

McArdle B.H., Anderson M.J. 2001. Fitting multivariate models to community data: a comment on distance-based redundancy analysis. Ecology 82: 290-297.

Menge B.A., Ashkenas L.R., Matson A. 1983. Use of artificial holes in studying community development in cryptic marine habitats in a tropical rocky intertidal region. Mar. Biol. 77: 129-142.

Metaxas A., Scheibling R.E. 1993. Community structure and organization of tidepools. Mar. Ecol. Prog. Ser. 98: 187-198.

Metaxas A., Hunt H.L., Scheibling R.E. 1994. Spatial and temporal variability of macrobenthic communities in tidepools on a rocky shore in Nova Scotia, Canada. Mar. Ecol. Prog. Ser. 105: 89-103.

Neto A.I. 2000. Observations on the biology and ecology of selected macroalgae from the littoral of São Miguel (Azores). Bot. Mar. 43: $483-498$
Pedersen M.F., Borum J., Fotel F.L. 2010. Phosphorus dynamics and limitation of fast- and slow-growing temperate seaweeds in Oslofjord, Norway. Mar. Ecol. Prog. Ser. 399: 103-115.

Reed D.C., Laur D.R., Ebeling A.W. 1988. Variation in algal dispersal and recruitment: the importance of episodic events. Ecol. Monogr. 58: 321-335.

Roberts D.E., Smith A., Ajani P., Davis A.R. 1998. Rapid changes in encrusting marine assemblages exposed to anthropogenic point-source pollution: a beyond BACI approach. Mar. Ecol. Prog. Ser. 163: 213-224.

Rubal M., Veiga P., Vieira R., Sousa-Pinto I. 2011. Seasonal patterns of tidepool macroalgal assemblages in the North of Portugal. Consistence between species and functional group approaches. J. Sea Res. 66: 187-194.

Sánchez I., Fernández C. 2005. Impact of the invasive seaweed Sargassum muticum (Phaeophyta) on an intertidal macroalgal assemblage. J. Phycol. 41: 923-930.

Sánchez I., Fernández C., Arrontes J. 2005. Long-term changes in the structure of intertidal assemblages after invasion by Sargassum muticum (Phaeophyta). J. Phycol. 41: 942-949.

Steen H. 2003. Intraspecific competition in Sargassum muticum (Phaeophyceae) germlings under various density, nutrient and temperature regimes. Bot. Mar. 46: 36-43.

Steneck R.S. 1986. The ecology of coralline algal crusts: convergent patterns and adaptive strategies. Annu. Rev. Ecol. Syst. 17: 273-303.

Terlizzi A., Anderson M.J., Fraschetti S., Benedetti-Cecchi L. 2007. Scales of spatial variation in Mediterranean subtidal sessile assemblages at different depths. Mar. Ecol. Prog. Ser. 332: 25-39.

Thompson R.C., Crowe T.P., Hawkins S.J. 2002. Rocky intertidal communities: past environmental changes, present status and predictions for the next 25 years. Environ. Conserv. 29: 168-191.

tom Dieck I. 1992. North Pacific and North Atlantic digitate Laminaria species (Phaeophyta): hybridization experiments and temperature responses. Phycologia 31: 147-163.

Underwood A.J. 1997. Experiments in Ecology: their logical design and interpretation using analysis of variance. Cambridge University Press, Cambridge, UK

Underwood A.J., Chapman M.G. 1996. Scales of spatial patterns of distribution of intertidal invertebrates. Oecologia 107: 212-224.

Underwood A.J., Petraitis P.S. 1993. Structure of intertidal assemblages in different locations: how can local processes be compared? In: Ricklefs R., Schutler D. (eds.) Species diversity in ecological communities. Univ. Chicago Press, Chicago, pp. $38-51$.

Underwood A.J., Skilleter G.A. 1996. Effects of patch-size on the structure of assemblages in rock pools. J. Exp. Mar. Biol. Ecol. 197: 63-90.

Underwood A.J., Chapman M.G., Connell S.D. 2000. Observations in ecology: you can't make progress on processes without understanding the patterns. J. Exp. Mar. Biol. Ecol. 250: 97-115.

Valdivia N., Scrosati R.A., Molis M., Knox A.S. 2011. Variation in community structure across vertical intertidal stress gradients: how does it compare with horizontal variation at different scales? PLoS ONE 6(8): e24062.

Van Tamelen P.G. 1996. Algal zonation in tidepools: experimental evaluation of the roles of physical disturbance, herbivory and competition. J. Exp. Mar. Biol. Ecol. 201: 197-231.

Viejo R.M. 1997. The effects of colonization by Sargassum muticum on tidepool macroalgal assemblages. J. Mar. Biol. Assoc. U.K. 77: 325-40.

Wilson D.P. 1970. Additional observations on larval growth and settlement of Sabellaria alveolata. J. Mar. Biol. Assoc. U.K. 50: $1-31$.

Wolfe J., Harlin M. 1988a. Tidepools in Southern Rhode Island, U.S.A. I. Distribution and seasonality of macroalgae. Bot. Mar. 31: 525-536.

Wolfe J., Harlin M. 1988b. Tidepools in Southern Rhode Island, U.S.A. II. Species diversity and similarity analysis of macroalgal communities. Bot. Mar. 31: 537-546.

Scient. ed.: E. Ballesteros.

Received May 25, 2012. Accepted September 26, 2012.

Published online November 26, 2012. 